\title{
Real-time prediction of rain-triggered lahars: incorporating seasonality and catchment recovery
}

\author{
Robbie Jones $^{1}$, Vern Manville ${ }^{1}$, Jeff Peakall ${ }^{1}$, Melanie J. Froude ${ }^{2, a}$, and Henry M. Odbert ${ }^{3, b}$ \\ ${ }^{1}$ School of Earth and Environment, University of Leeds, Leeds, LS2 9JT, UK \\ ${ }^{2}$ School of Environmental Sciences, University of East Anglia, Norwich, NR4 7TJ, UK \\ ${ }^{3}$ School of Earth Sciences, University of Bristol, Wills Memorial Building, Queens Road, Bristol BS8 1RJ, UK \\ a now at: Department of Geography, University of Sheffield, 9 Northumberland Road, Sheffield, S10, UK \\ b now at: Met Office, FitzRoy Road, Exeter, Devon, EX1 3PB, UK
}

Correspondence: Robbie Jones (robbie_j_jones@outlook.com)

Received: 10 May 2017 - Discussion started: 23 May 2017

Revised: 16 September 2017 - Accepted: 21 October 2017 - Published: 13 December 2017

\begin{abstract}
Rain-triggered lahars are a significant secondary hydrological and geomorphic hazard at volcanoes where unconsolidated pyroclastic material produced by explosive eruptions is exposed to intense rainfall, often occurring for years to decades after the initial eruptive activity. Previous studies have shown that secondary lahar initiation is a function of rainfall parameters, source material characteristics and time since eruptive activity. In this study, probabilistic rain-triggered lahar forecasting models are developed using the lahar occurrence and rainfall record of the Belham River valley at the Soufrière Hills volcano (SHV), Montserrat, collected between April 2010 and April 2012. In addition to the use of peak rainfall intensity (PRI) as a base forecasting parameter, considerations for the effects of rainfall seasonality and catchment evolution upon the initiation of raintriggered lahars and the predictability of lahar generation are also incorporated into these models. Lahar probability increases with peak $1 \mathrm{~h}$ rainfall intensity throughout the 2-year dataset and is higher under given rainfall conditions in year 1 than year 2. The probability of lahars is also enhanced during the wet season, when large-scale synoptic weather systems (including tropical cyclones) are more common and antecedent rainfall and thus levels of deposit saturation are typically increased. The incorporation of antecedent conditions and catchment evolution into logistic-regression-based raintriggered lahar probability estimation models is shown to enhance model performance and displays the potential for successful real-time prediction of lahars, even in areas featuring strongly seasonal climates and temporal catchment recovery.
\end{abstract}

\section{Introduction}

Lahars are rapidly flowing mixtures of rock debris and water (other than normal streamflow) from a volcano and represent a significant hazard due to their energetic nature and mobility (Smith and Fritz, 1989). Globally, $17 \%$ of historical volcanorelated fatalities have occurred due to lahars (Auker et al., 2013), with decadal-scale hazards being created by some large eruptions (Major et al., 2000). Secondary, post-eruption lahars are dominantly the result of rainfall on unconsolidated pyroclastic deposits, which are typically remobilised by rilling due to Hortonian overland flow (Segerstrom, 1950; Waldron, 1967), undercutting and lateral bank collapse, and headward erosion (Pierson, 1992) or by shallow landsliding of saturated tephra layers above basal décollement surfaces (Iverson, 2000; Manville et al., 2000).

At present, rain-triggered lahar hazard identification is predominantly based on observations as well as groundbased flow detection systems such as acoustic flow monitors (AFMs) or trip wires at locations where such resources are available (e.g. Marcial et al., 1996; Lavigne et al., 2000). Previous studies featuring post-lahar analysis of flow observations and rainfall records at a range of volcanoes have displayed a power-law relationship indicating that lahar initiation occurs along a continuum from short-duration, high-intensity rainfall events to long-duration, low-intensity events (e.g. Rodolfo and Arguden, 1991; Capra et al., 2010; Jones et al., 2015). Enhancing the use of local telemetered rainfall gauge networks within lahar hazard monitoring and assessment has the potential to increase the number of avail- 
able mitigation tools whilst avoiding the lag time between flow initiation and flow detection inherent in ground-based detection and observation. Globally, such pre-emptive prediction and forecasting of rain-triggered lahars based on telemetered rainfall data is lacking, although the initial application of real-time rainfall data for lahar prediction has demonstrated increased lahar warning times compared with ground-based flow detection (Jones et al., 2015).

The initiation of rain-triggered lahars is dependent on the characteristics of rainfall, pyroclastic deposits and topography, indicating that both the climatic regime of laharprone regions and the hydrogeomorphic response of drainage basins to eruptive activity are important considerations in rain-triggered lahar research (Pierson and Major, 2014). Regions of high rainfall seasonality are predominantly distributed in the tropics and subtropics on either side of the equator (Wang et al., 2010), whilst approximately $46 \%$ of active volcanoes are identified as being located in the humid tropics (Rodolfo and Arguden, 1991). Despite this geographic coincidence and the importance of climatic rainfall regimes on storm intensities, durations and antecedent conditions (all significant factors in lahar initiation, Pierson and Major, 2014), the impact of seasonal rainfall on raintriggered lahar initiation has not previously been explicitly considered within the development of rain-triggered lahar hazard assessment tools.

Following a discrete volcanic eruption, sediment yields in impacted fluvial systems are amongst the highest recorded globally, but decline exponentially (Major et al., 2000), which is consistent with other examples of disturbed earth systems (Graf, 1977). Mechanisms include a reduction in available particulate material, vegetation recovery, fragmentation of runoff-enhancing surface crusts, exposure of more permeable substrates and the stabilisation of rill networks (Leavesley et al., 1989; Schumm and Rea, 1995; Major et al., 2000; Major and Yamakoshi, 2005). Conversely, at locations featuring recurrent or persistent volcanic activity, the magnitude of the lahar hazard remains relatively constant with time due to the regular supply of new material (Thouret et al., 2014). As a result, temporal catchment development is another factor influencing lahar frequency and magnitude through time and should also be considered within the development of rain-triggered lahar hazard assessment tools.

This study uses probabilistic and diagnostic methods, including binary logistic regression and receiver operating characteristic (ROC) analysis, to develop real-time rainfallbased lahar forecasting tools which account for the impacts of seasonal rainfall and catchment recovery on lahar occurrence in the Belham valley, Montserrat. Such hazard assessment tools have the potential to be utilised both as a standalone tool where ground-based detection equipment is unavailable and in conjunction with instrumental monitoring techniques to increase lahar warning times.

\section{Soufrière Hills volcano, Montserrat}

The Soufrière Hills volcano (SHV, Montserrat, Lesser Antilles; $16.72^{\circ} \mathrm{N}, 62.18^{\circ} \mathrm{W}$ ) lies on the northern edge of the Inter-Tropical Convergence Zone in the eastern Caribbean and has a strongly seasonal climate. Rainfall-producing weather systems affecting the island fall into two broad categories: large-scale synoptic ( $>100 \mathrm{~km}$ across) systems and local mesoscale $(<100 \mathrm{~km}$ across) systems (Froude, 2015). Both can produce high-intensity precipitation, but large-scale events can potentially be forecast days in advance whereas this timescale reduces to hours for local weather systems (Barclay et al., 2006).

The andesitic dome-forming eruption of SHV began in July 1995 and has featured several phases of activity consisting of dome growth, dome collapse and Vulcanian explosions as well as pauses in magma extrusion (Bonadonna et al., 2002; Komorowski et al., 2010; Stinton et al., 2014). Pyroclastic density currents (PDCs) have deposited fine-grained, ash- and pumice-rich, and coarser-grained blocky deposits around the volcano (Cole et al., 2002; Stinton et al., 2014), supplemented by tephra deposits from short-lived Vulcanian explosions and associated fountain-collapse flows and surges (Komorowski et al., 2010). Prevailing winds often distribute ash from weak plumes to the west, but larger plumes can also deposit to the north, east and south (Bonadonna et al., 2002). This intermittent eruptive activity has triggered a complex sedimentological response in drainages surrounding the volcano since 1995 (Barclay et al., 2006, 2007; Alexander et al., 2010; Froude, 2015).

\section{The Belham catchment}

Data from the Belham valley, Montserrat (Fig. 1), were used to examine the influence of rainfall seasonality and catchment evolution on the occurrence of rain-triggered lahars between April 2010 and April 2012 (Fig. 2). Lahars have persisted in the valley since the onset of eruptive activity in 1995, and detailed observations of lahars in the Belham valley have indicated that they are dominantly Newtonian and fully turbulent (Barclay et al., 2007; Alexander et al., 2010; Froude et al., 2017). Lahars have damaged infrastructure, including the burying of the Belham bridge in 1998, resulting in the riverbed being used as the primary transportation link between the "safe zone" and the "daytime entry zone" (Barclay et al., 2007; Alexander et al., 2010).

The Belham catchment had a pre-1995 surface area of ca. $13.7 \mathrm{~km}^{2}$, increasing to ca. $14.8 \mathrm{~km}^{2}$ early in the eruptive episode due to the capture of a portion of the Gages fan (Froude, 2015). During eruptive episodes tephra fall and pyroclastic density current deposits accumulate in the upper catchment. The destruction and burial of vegetation in the Belham valley reduces the infiltration and interception of precipitation and in combination with a reduction in sur- 


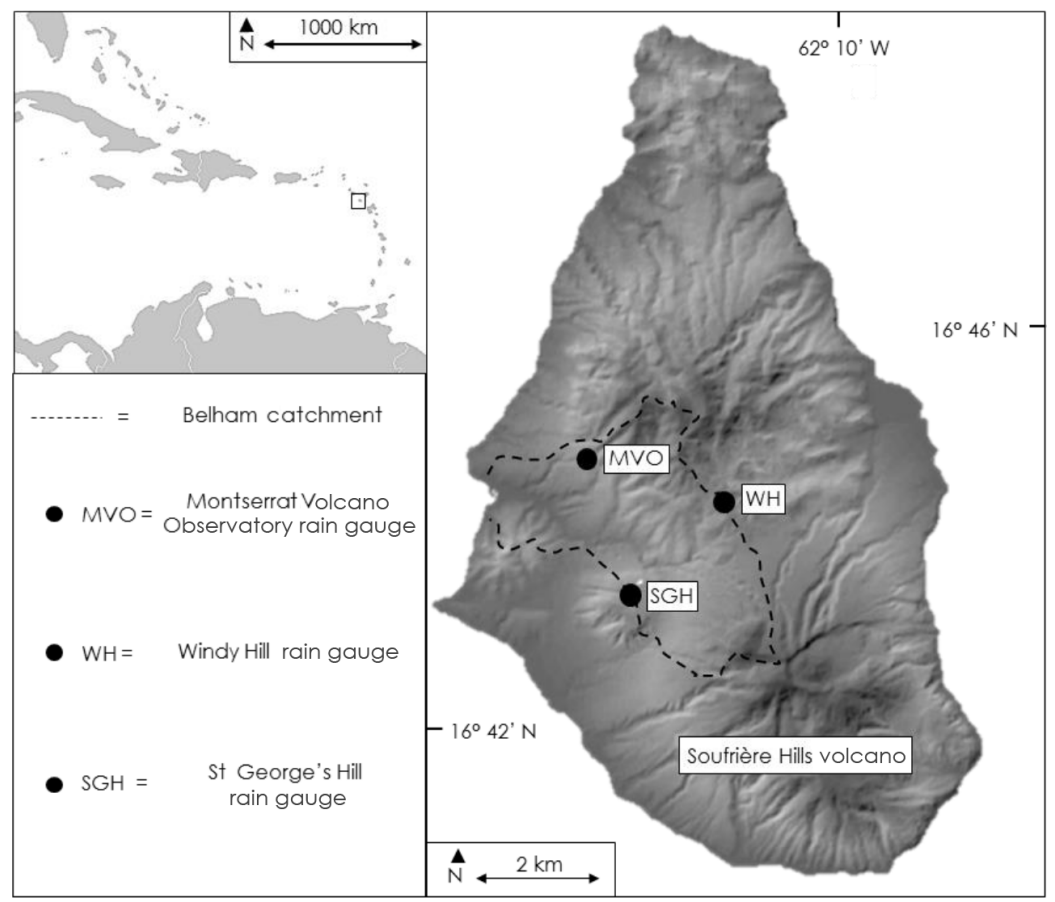

Figure 1. Location map of Montserrat and the Soufrière Hills volcano.

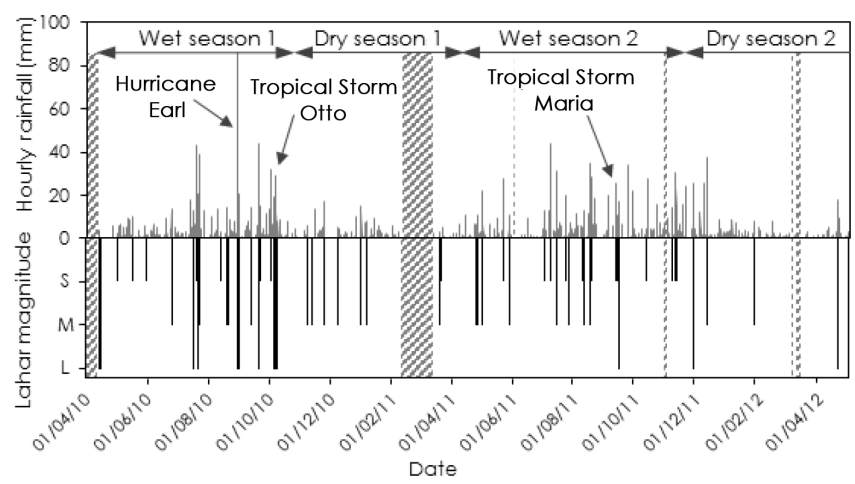

Figure 2. Timeline illustrating hourly rainfall data (above) and raintriggered lahar activity (below) in the Belham valley, Montserrat, between April 2010 and April 2012 (with minor gaps, stippled ornament, due to equipment failure). S, M and $\mathrm{L}$ on the vertical axis represent small, medium and large lahars respectively; see text for details.

face roughness enhances runoff and erosion rates and promotes rain-triggered lahar generation (Barclay et al., 2007; Alexander et al., 2010; Froude, 2015). Prior to the onset of eruptive activity, $62 \%$ of the Belham catchment was densely vegetated with dry forest $(29 \%)$, mesic forest $(48 \%)$ and wet forest $(13 \%)$, with dry forest subsequently identified as the dominant species found on revegetating pyroclastic deposits (Froude, 2015). Previous studies in the Belham valley have not identified evidence of hydrophobicity, such as previously identified at Colima by Capra et al. (2010). Aggrada- tion and sedimentation in the upper catchment during periods of eruptive activity are counterbalanced during periods of quiescence by channel development and stabilisation, exposure of more permeable substrates, vegetation recovery and a reduction in available sediment (Froude, 2015). The data period used here coincides with a lack of substantial eruptive activity at SHV following the 11 February 2010 dome collapse at the end of "phase 5", which deposited stacked lobes of pumiceous PDC deposits up to $5.7 \mathrm{~km}$ from the source in the Belham valley (Stinton et al., 2014). This period of eruptive quiescence indicates that this study focuses on a time of channel development and stabilisation within the upper catchment of the Belham valley.

\section{Methods}

The record used in this study (Fig. 2) comprises $0.1 \mathrm{~mm}$ resolution hourly precipitation data recorded at the Montserrat Volcano Observatory helipad gauge between February 2010 and February 2011, the St George's Hill gauge between March 2011 and May 2011, and the maximum of the St George's Hill and Windy Hill gauges (Fig. 1) between May 2011 and February 2012. While a continuous record from rain gauges with a better spatial distribution and density would be ideal to minimise differences in catch efficiencies and to capture local variations in convective and orographic rainfall, operating a fully functioning rain gauge network is technically challenging and generally a low priority during a volcanic crisis. The lahar database (Fig. 2) is com- 
piled from inspection of seismic records and visual observations and lahars are categorised based on magnitude (small, medium, large). These categories were assessed using visual inspection of the degree of channel inundation and flow depth (where possible), in addition to the assessment of the duration and amplitude of seismic signals. Seismic signals of lahars show continuous readings in the $2-5 \mathrm{~Hz}$ and peak at approximately $30 \mathrm{~Hz}$. The highest recorded amplitudes are associated with the greatest discharges and sediment loads in observed lahars. Lahar signals were cross referenced to visual observations and carefully excluded from signals associated with primary volcanic activity and other seismic noise (such as construction vehicles).

Within this study a designated minimum inter-event dry period of $6 \mathrm{~h}$ is utilised, meaning that in common with several previous soil erosion studies a dry interval of $6 \mathrm{~h}$ is needed to define the end of a single rainfall event (Wischmeier and Smith, 1978; Todisco, 2014). Figure 3 shows six examples of rainfall events (or series of consecutive rainfall events) which resulted in the observation or detection of lahars in the Belham valley, clearly displaying the lag time between the recording of rainfall (cumulative- and real-time progression of $1 \mathrm{~h}$ peak rainfall intensity, $1 \mathrm{hPRI}$ ) and the observation/detection of lahars. The $1 \mathrm{hPRI}$ has been identified as an effective parameter in lahar initiation threshold assessment during previous analysis (Jones et al., 2015). Division of the dataset into 6-month moving windows, with staggered 1-month start dates, facilitates the illustration of the seasonal variation in both the number of rainfall events exceeding $1 \mathrm{hPRI}$ thresholds and the occurrence (and estimated magnitude) of lahars (Fig. 4).

This study uses binary logistic regression to develop lahar probability estimation models based on the $1 \mathrm{hPRI}$ of a rainfall event, whilst also examining the impacts of incorporating considerations for seasonal and temporal effects within these models. Binary logistic regression is a statistical method that estimates the probability of a dichotomous outcome (the occurrence or non-occurrence of lahars in this case) using one or more independent variables (Hosmer et al., 2013). Model performance is assessed using both the model chi-square test and receiver operating characteristic analysis (Fawcett, 2006). ROC analysis (Appendix) plots the true-positive rate (TPR) against the false-positive rate (FPR) as a threshold (estimated lahar probability in this instance) is varied in order to assess how effectively the parameter discriminates between lahar- and non-lahar-producing rainfall events. The area under the ROC curve (AUC) is a measure of the ability of a tool to distinguish between the two outcomes and varies between 0.5 (no predictive ability, i.e. number of true positives equals number of false positives, or no better than guessing) and 1.0 (perfect predictive ability, i.e. $100 \%$ true positives and no false positives).

\section{Results}

The 6-month window between April and October is identified as the peak wet season in this study, with $1721 \mathrm{~mm}$ of recorded rainfall in the 2010 peak wet season (WS1) and $1455 \mathrm{~mm}$ in the 2011 peak wet season (WS2). The 20102011 peak dry season (DS1) featured approximately $750 \mathrm{~mm}$ of rainfall, whilst $1076 \mathrm{~mm}$ of rainfall was recorded in the 2011-2012 peak dry season (DS2). Mean WS1 and WS2 $1 \mathrm{hPRIs}$ are 5.2 and $5.0 \mathrm{~mm} \mathrm{~h}^{-1}$ respectively, whilst mean dry season $1 \mathrm{hPRIs}$ are $2.2 \mathrm{mmh}^{-1}$ (DS1) and $3.3 \mathrm{~mm} \mathrm{~h}^{-1}$ (DS2).

There is significant $(p<0.01)$ correlation between recorded rainfall on timescales of $1-168 \mathrm{~h}$ and lahar occurrence. When lahars are categorised by estimated magnitude, large lahars are strongly correlated with longer-duration $(>24 \mathrm{~h}$ ) rainfall events produced by the passage of synoptic weather systems. Between April 2010 and April 2012 large flows were directly attributed to several named tropical cyclones (Fig. 2). In contrast, smaller lahars display increased correlation with the passage of short-duration $(<$ $24 \mathrm{~h}$ ) rainfall events, which is more commonly associated with mesoscale weather systems.

\subsection{Probabilistic rain-triggered lahar analysis}

The correlation between recorded peak rainfall intensity and the subsequent occurrence of lahars (Fig. 3) provides the platform for probabilistic analysis of lahar occurrence based on the $1 \mathrm{hPRI}$ of a rainfall event. Results show that lahar probability increases with greater $1 \mathrm{hPRI}$ throughout the 2year study period. For example, of the 18 rainfall events which exceeded a $1 \mathrm{hPRI}$ of $25 \mathrm{~mm} \mathrm{~h}^{-1}, 15$ were associated with the triggering of lahars, and all of the rainfall events exceeding a $1 \mathrm{hPRI}$ of $34 \mathrm{~mm} \mathrm{~h}^{-1}$ triggered lahars. Additionally, higher lahar probabilities are observed in year 1 than year 2 for a specified $1 \mathrm{hPRI}$ (Fig. 5), and empirically derived lahar probabilities for rainfall events featuring a given minimum $1 \mathrm{hPRI}$ also fluctuate seasonally during the study period (Fig. 6). These $1 \mathrm{~h}$ PRI exceedance-based lahar probabilities (Fig. 6) are initially stable during the 6-month windows focused on WS1 before decreasing during DS1, increasing during WS2 and once again decreasing into DS2. This indicates that more intense rainfall is required to trigger lahars in the dry season than in the wet season. Throughout the 2year study period, increased $1 \mathrm{hPRI}$ correlates with increased lahar probability, displaying its effectiveness as a potential first-order lahar forecasting parameter.

In addition to seasonal fluctuations in relative lahar probability, there is an overall decline in relative lahar probabilities across the 2-year study period (Figs. 5 and 6). The relationship between $1 \mathrm{hPRI}$ and lahar occurrence and the combination of seasonal fluctuation and temporal decline in lahar probability displayed in Fig. 6 are examined further using binary logistic regression. In this instance the occurrence or 

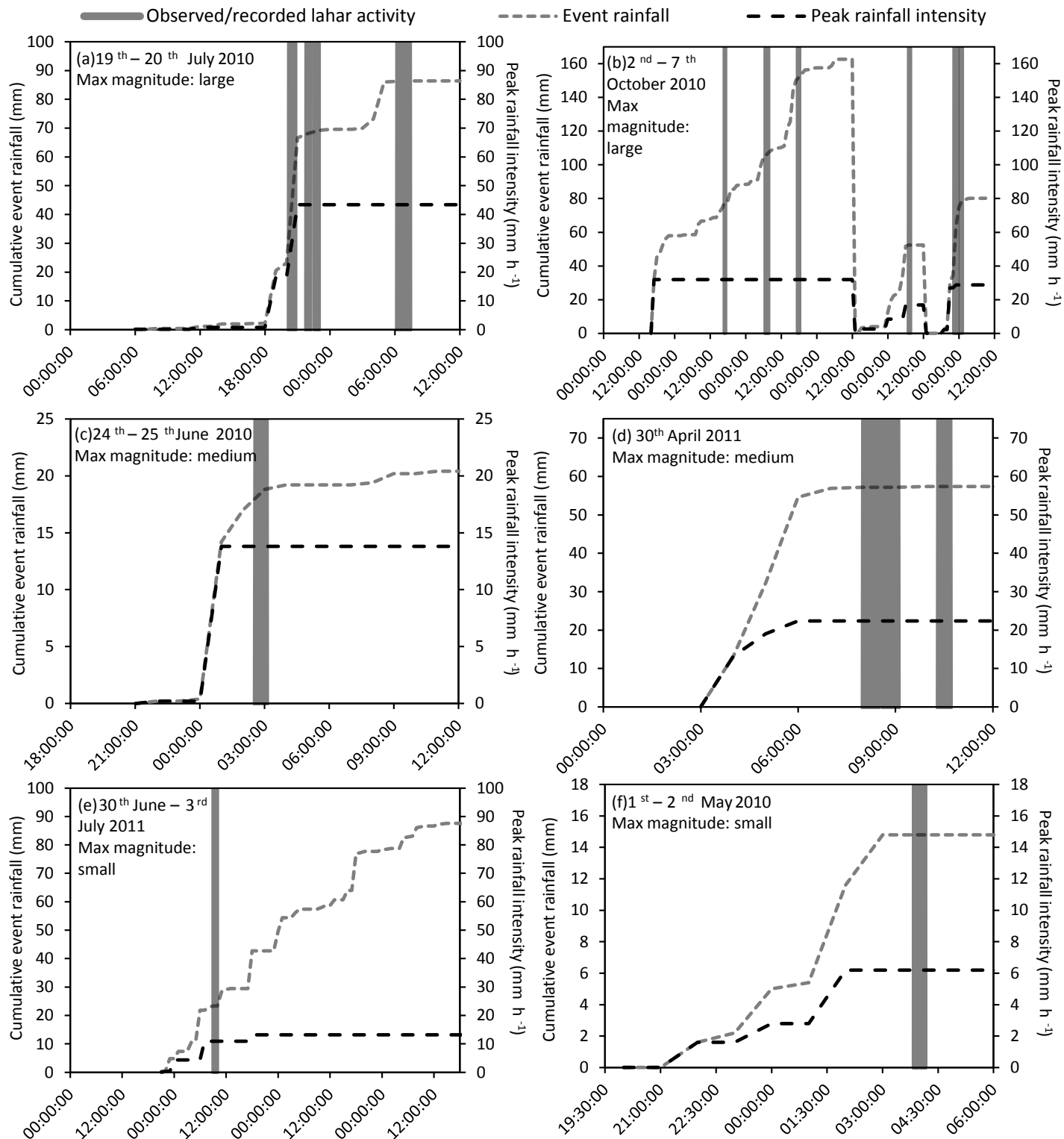

Figure 3. Timelines displaying examples of lahar-triggering rainfall in the Belham valley, Montserrat, between April 2010 and April 2012. Alongside the timing of lahar observation and/or detection, the cumulative recorded rainfall $(\mathrm{mm})$ and $1 \mathrm{~h}$ peak rainfall intensity $(1 \mathrm{hPRI}-$ $\mathrm{mm} \mathrm{h}^{-1}$ ) of the rainfall events are displayed.

non-occurrence of lahars (of any magnitude) is used as the dichotomous dependent variable and initially the $1 \mathrm{hPRI}$ of a rainfall event is the singular independent variable. Figure 7 displays logistic-regression-based lahar probability estimation models generated by this single-variable approach using four sub-datasets: year 1, year 2, wet seasons and dry seasons. Within each of these four models the model chi-square test indicated statistically significant lahar prediction ability $(p<0.01)$. Figure 7 displays higher estimated lahar probabilities at identical $1 \mathrm{~h}$ PRI values for year 1 relative to year 2 and wet seasons relative to dry seasons.
The potential benefit of incorporating considerations for seasonal and temporal effects within lahar forecasting models was investigated using further binary logistic regression. This approach selected alternate chronological rainfall events (minimum total rainfall $\geq 8 \mathrm{~mm}$ ) from the 2-year dataset, creating a model formulation dataset consisting of 74 rainfall events, of which 25 produced lahars. Lahar forecasting models were created from this model formulation dataset using binary logistic regression, and the remaining 73 rainfall events, of which 20 produced lahars, were retained for the assessment of the performance of the lahar forecasting models. Proxies for seasonal effects (antecedent rainfall on timescales 


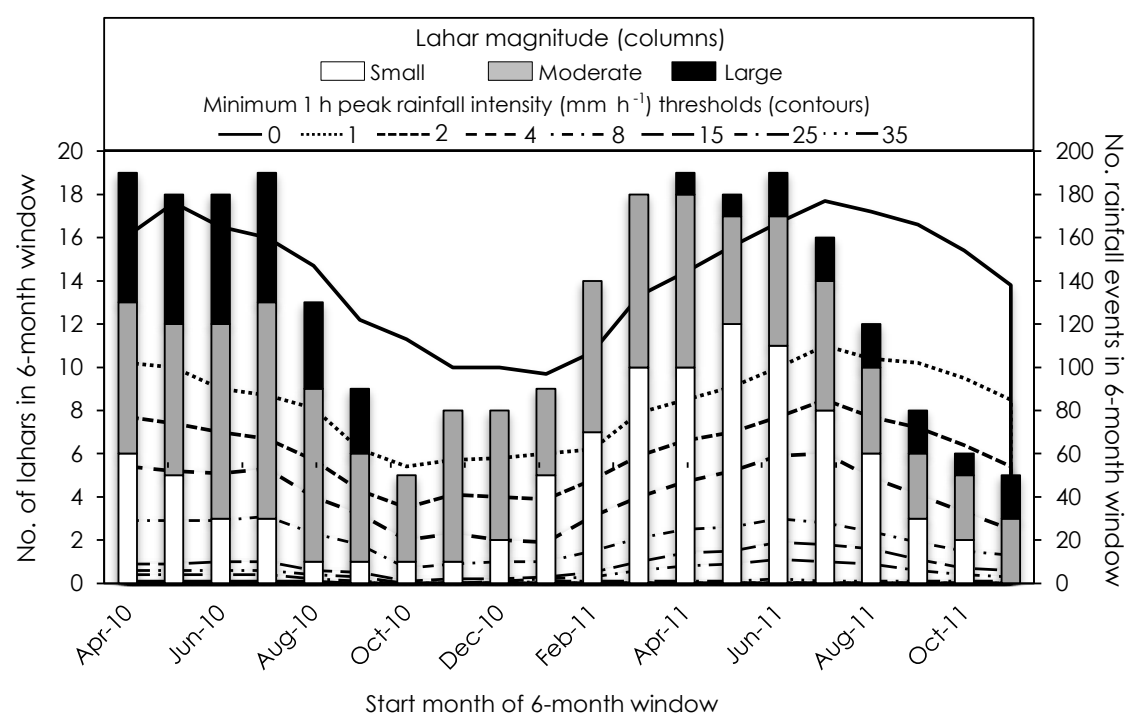

Figure 4. Illustration of the seasonal fluctuations in lahar occurrence displayed using 6-month data windows with 1-month staggered start dates. Vertical bars indicate the number of lahar events, categorised by magnitude, in each 6-month period. Background contours display the number of rainfall events exceeding specified $1 \mathrm{~h}$ peak rainfall intensity ( $1 \mathrm{hPRI}$ ) thresholds in each 6-month period.

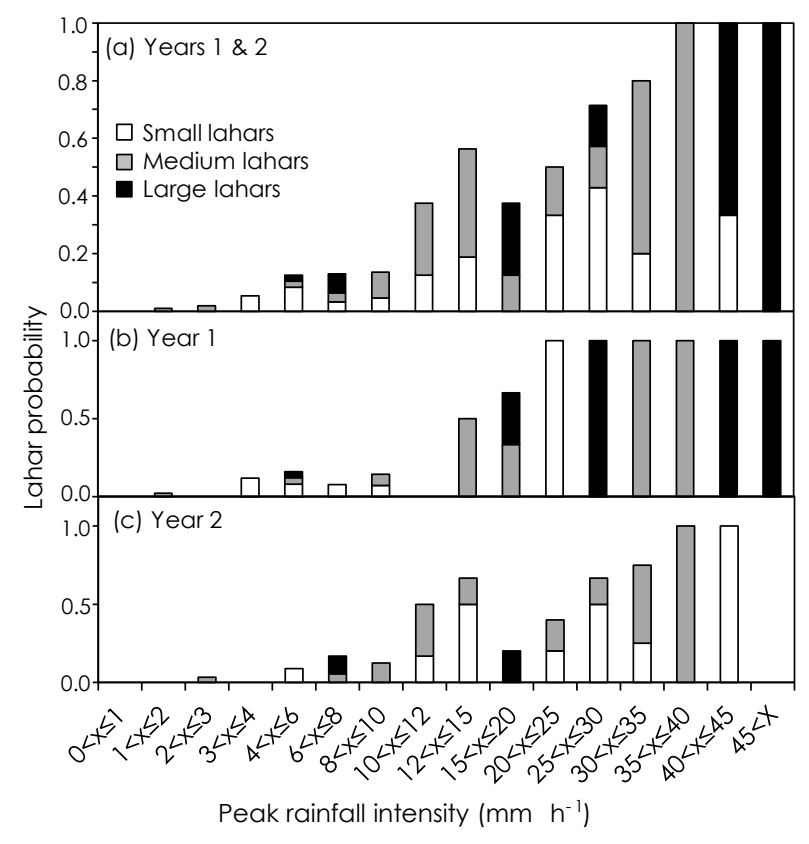

Figure 5. Lahar probability, classified by magnitude, as categorised $1 \mathrm{~h}$ peak rainfall intensity (1 hPRI) increases. (a) April 2010April 2012; (b) April 2010-April 2011; (c) April 2011-April 2012.

of 1-90 days) and catchment recovery (long-term cumulative rainfall and days since significant eruptive activity) were tested in combination with $1 \mathrm{~h}$ PRI. The minimum event rainfall threshold of $8 \mathrm{~mm}$ (under which only two lahars occurred during the 2-year dataset) was implemented for logistic regression and subsequent forecasting assessment in order to increase the balance between lahar and non-lahar outcomes and thus reduce skewed predicted probability.

Three-day antecedent rainfall displayed the biggest influence of the tested antecedent rainfall timescales upon the effectiveness of lahar forecasts, while total cumulative rainfall since significant eruptive activity (i.e. the end of phase 5) best captured temporal catchment development effects. Therefore, the optimal lahar forecasting model developed from the model formulation dataset utilises 3-day antecedent rainfall and long-term cumulative rainfall alongside the first-order lahar forecasting parameter of $1 \mathrm{~h}$ PRI. A 3-day antecedent period was also used by Capra et al. (2010) at Colima, whereas a 7-day period was used in Indonesia (Lavigne et al., 2000; Lavigne and Suwa, 2004) where rainfall is higher and evaporation rates are lower, and a $24 \mathrm{~h}$ period was used at Mount Yake-dake (Okano et al., 2012). The optimal antecedent rainfall timescale is a function of local climate (Capra et al., 2010) and the grain-size distribution of the pyroclastic deposits (Rodolfo and Arguden, 1991).

The reverse stepwise logistic regression method (Hosmer et al., 2013), which involves the deletion of variables whose removal from the model results in a statistically insignificant deterioration of model performance, retained these three independent variables (1 hPRI, 3-day antecedent rainfall and total cumulative rainfall since significant eruptive activity). This model composition increased the correct classification of rainfall event outcomes in the model formulation dataset from a null model value of $66 \%$ (when all events in the database are predicted to not trigger lahars) to $80 \%$ when using our explanatory variables, with model chi-square tests again indicating significant prediction ability $(p<0.01)$. Model variables $\left(X_{i}\right)$ and output regression coefficients $\left(\beta_{i}\right)$ 


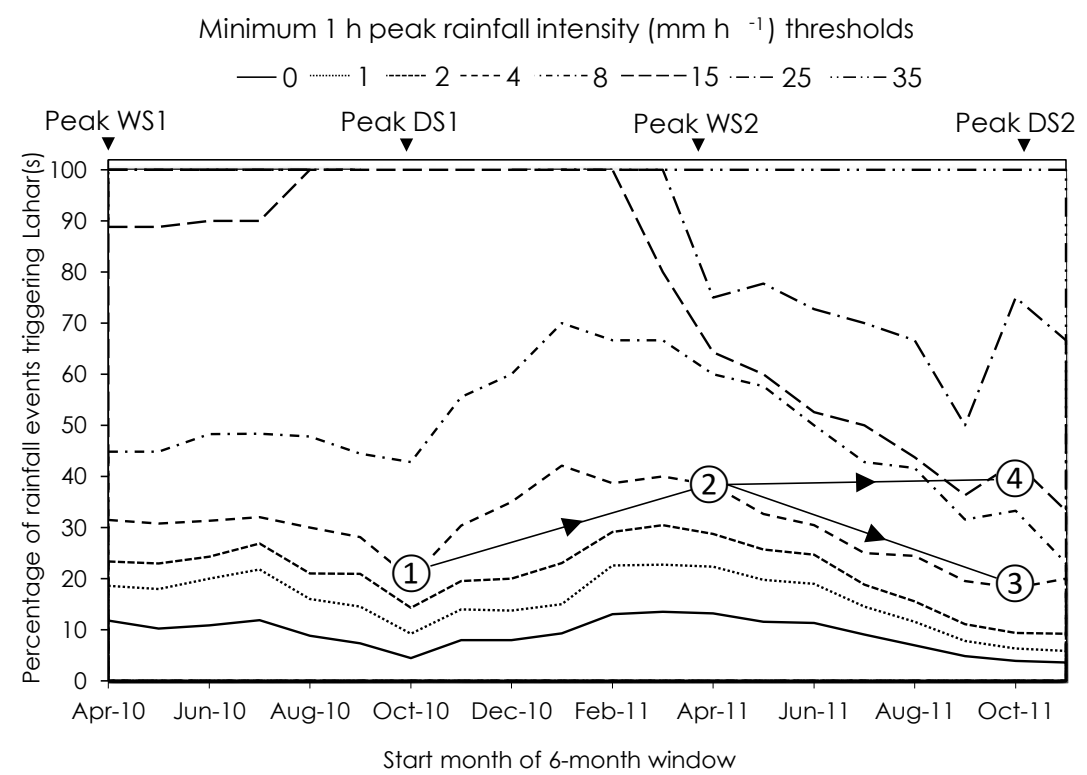

Figure 6. Seasonal and temporal effects on lahar probability. Contour graph of empirically derived lahar probability relative to the exceedance of $1 \mathrm{~h}$ peak rainfall intensity ( $1 \mathrm{hPRI})$ thresholds in 6-month moving data windows with 1-month staggered start dates. White numbers and dashed lines show temporal trends. Following the empirically derived $4 \mathrm{~mm} \mathrm{~h}^{-1}$ PRI contour, there is a $20 \%$ probability of a lahar if this threshold is exceeded at " 1 " (6-month start date of 13 October 2010). This probability increases to $38 \%$ at " 2 " (13 April 2011$)$ and declines to $18 \%$ at " 3 " (13 October 2011). Alternatively, reading horizontally across the graph for a lahar probability of $38 \%$, the associated PRI threshold increases from $4 \mathrm{mmh}^{-1}$ at " 2 " (13 April 2011) to approximately $15 \mathrm{mmh}^{-1}$ at " 4 " (13 October 2011).

are used to construct lahar probability estimation equations by conversion of the logistic regression logit model (Eq. 1) in terms of probability.

$\operatorname{logit}(p)=\beta_{0}+\beta_{1} X_{1}+\beta_{2} X_{2}+\cdots+\beta_{n} X_{n}$

Equation (2) displays the application of this to the multivariable model, featuring the probability of lahar occurrence $(p)$, $1 \mathrm{hPRI}\left(R_{i}\right)$, 3-day antecedent rainfall $\left(A_{3}\right)$ and cumulative rainfall since significant eruptive activity $(C)$.

$p=\frac{1}{1+e^{-\left(-2.10+0.133 R_{i}+0.018 A_{3}-0.215 C\right)}}$

Equation (3) displays the lahar probability estimation model produced by the same dataset using only $1 \mathrm{hPRI}$ as an independent variable.

$p=\frac{1}{1+e^{-\left(-2.33+0.133 R_{i}\right)}}$

Application of Eqs. (2) and (3) to the 73 rainfall events in the forecasting assessment dataset produced two sets of model-derived lahar probability estimates. The lahar forecasting performance of the two models was then assessed relative to the actual outcomes (lahar or no lahar) of the rainfall events using ROC analysis. The multiple-variable lahar probability estimation model shown in Eq. (2) produced an AUC of $0.83(p<0.01)$, whilst the single variable model shown in Eq. (3) produced an AUC of $0.79(p<0.01)$ (Fig. 7b). The
AUC produced by Eq. (2) increases to 0.93 if the $8 \mathrm{~mm}$ event threshold is removed and the multivariable model is applied to all 508 rainfall events that were not used in model formulation (AUC given by Eq. (3) increases to 0.89 for equivalent parameters).

\section{Discussion}

Analysis of the Belham valley lahar occurrence and rainfall record over a 2-year period indicates that lahar probability and magnitude is a function of (i) temporal catchment evolution towards more stable conditions - lahars are harder to trigger with time; and (ii) seasonal variations in rainfall - lahars are more common in the wet season both in terms of frequency and probability relative to $1 \mathrm{hPRI}$.

The multi-year temporal trend is attributed to a declining supply of easily erodible pyroclastic material in the upper catchment, coupled with stabilisation of channel networks, vegetation regrowth and increased infiltration as identified in several previous studies of lahar-prone regions following eruptive activity (e.g. Leavesley et al., 1989; Schumm and Rea, 1995; Major et al., 2000; Major and Yamakoshi, 2005). However, direct comparisons with other lahar-prone settings is not possible as differences in methodologies mean that common metrics such as sediment yield were not determined. The occurrence of several large rainfall events following phase 5 of the eruption (8 October 2009 to 11 February 

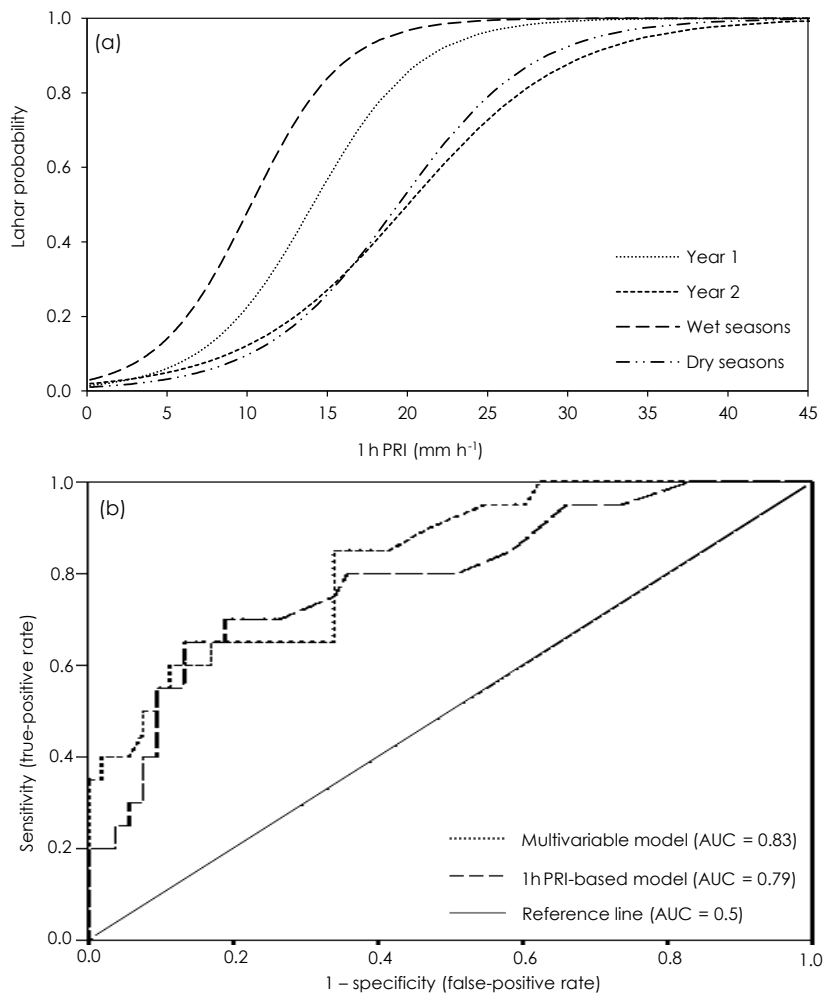

Figure 7. Assessment of binary-logistic-regression-based lahar probability estimation models in the Belham valley, Montserrat. (a) Illustration of four binary-logistic-regression-based lahar probability estimation models created from year 1, year 2, wet season and dry season data. (b) ROC curves assessing the lahar forecasting performance of an exclusively $1 \mathrm{~h}$ peak rainfall intensity ( $1 \mathrm{hPRI}$ )centric logistic-regression-based lahar probability estimation model and a multivariable ( $1 \mathrm{hPRI}$, antecedent rainfall and long-term cumulative rainfall) model.

2010) triggered a number of high-magnitude lahars within the Belham valley, enhancing temporal channel development within the catchment and resulting in the widespread erosion and downstream transportation of pyroclastic material (Froude, 2015). Rapid revegetation during periods of eruptive quiescence has also been identified in the catchment (Froude, 2015) - a process which increases infiltration, interception, evapotranspiration and surface roughness, reducing post-eruption runoff rates (Yamakoshi and Suwa, 2000; Ogawa et al., 2007; Alexander et al., 2010). The temporal increase in infiltration rates in the Belham valley is also attributed to the exposure of more permeable substrates following the erosion of fine-grained surface tephra layers (Froude, 2015), which is a factor identified previously in studies of the landscape response to the 1980 eruption of Mt St Helens (Collins and Dunne, 1986; Leavesley et al., 1989). Collectively these processes would result in increasing lahar initiation thresholds with time (Van Westen and Daag, 2005).
Probabilistic analysis shows that, throughout the 2-year dataset utilised in this study, increased $1 \mathrm{hPRI}$ results in increased lahar occurrence probability. Additionally, an increase in the absolute numbers of lahars and a reduction in rain-triggered lahar initiation thresholds are identified in the wet seasons. The seasonality in nature and the frequency of rainfall-generating weather systems control this pattern. Large lahars are often associated with the passage of synoptic weather systems, which typically produce long-duration catchment-wide rainfall. This is demonstrated by the triggering of large lahars by several named storms during the study dataset including Hurricane Earl in August 2010, Tropical Storm Otto in October 2010 and Tropical Storm Maria in September 2011. Increased rainfall in the wet season also influences antecedent conditions within the catchment, resulting in reduced infiltration rates due to deposit saturation (Barclay et al., 2007). Increased antecedent rainfall can also produce runoff-enhancing surface seals (Segerstrom, 1950; Fohrer et al., 1999) and result in increased bulking efficiency during lahar transit due to high water contents in channel floor deposits (Iverson et al., 2011). These effects increase the overall probability of lahars in the wet season under given rainfall conditions due to flash-flood-type responses to rainfall. The reduced frequency of large lahars in the dry season is attributed to the occurrence of fewer sustained catchmentwide synoptic weather systems as well as antecedent effects (low antecedent rainfall inhibits bulking efficiency in the dry season; Fagents and Baloga, 2006; Doyle et al., 2011; Iverson et al., 2011). The development of lahar magnitude assessment methods, from the subjective classification used in this study towards quantitative initial flow volume estimates, has the potential to enhance probabilistic lahar forecasting by creating probabilistic hazard footprints (Mead et al., 2016). However, such quantitative assessment methods are highly data intensive relative to those developed in this study, requiring pre- and post-eruption digital elevation models, location-specific rainfall intensity-frequencyduration thresholds and physical deposit characteristics as input data (Mead et al., 2016). These input data requirements prohibit practical implementation of fully quantitative magnitude estimates within probabilistic rain-triggered lahar assessment at all but the most thoroughly monitored volcanoes.

The incorporation of considerations for temporal catchment development and seasonality of prevalent antecedent conditions into logistic-regression-based lahar probability estimation models increases rain-triggered lahar forecasting performance. The addition of these considerations modulates purely $1 \mathrm{~h}$ PRI-based probability estimates to account for the initial deposit moisture content and the degree of catchment recovery during a period of eruptive quiescence. ROC analysis indicates an excellent ability to differentiate between lahar and non-lahar outcomes (AUC $=0.83$ ) when only larger rainfall events resulting in $\geq 8 \mathrm{~mm}$ of total rainfall are considered, and this ability improves even further $(\mathrm{AUC}=0.93)$ when the $8 \mathrm{~mm}$ threshold is removed. The readily available 
model inputs of $1 \mathrm{~h}$ PRI, 3-day antecedent rainfall and cumulative rainfall since significant eruptive activity can be easily assimilated into functional real-time lahar probability estimation models and produce real benefits. Rainfall gauge networks in volcanic areas are seldom designed with the intention of optimising their usefulness for the detection and characterisation of rain-triggered lahar initiation: the $1 \mathrm{hPRI}$ used in this study is based on the minimum temporal resolution of the data recorded. Previous studies have shown the utility of 10 min (Arguden and Rodolfo, 1990; Tungol and Regalado, 1996; Lavigne et al., 2000; Lavigne and Suwa, 2004; Okano et al., 2012; Jones et al., 2015), $30 \mathrm{~min}$ (Tungol and Regalado, 1996; Lavigne et al., 2000; Jones et al., 2015) and 60 min (Lavigne et al., 2000; Lavigne and Suwa, 2004; Jones et al., 2015) rainfall data. Lahar forecasting using real-time telemetered rainfall data and these techniques has the potential to effectively predict secondary lahars and increase lahar warning times, even in areas where AFMs, proximal seismometers and trip wires are unavailable. Used in conjunction with ground-based detectors in instrumented catchments, lahar warning times can be doubled (Jones et al., 2015).

Further research to expand the length of the current 2year study period would develop the understanding of the catchment recovery-driven temporal trends in lahar occurrence identified within this study. Likewise, the application of these techniques to additional volcanoes would facilitate both the further examination of the performance of the lahar forecasting models and the investigation of other important parameters contributing to the frequency and magnitude of rain-triggered lahar initiation.

\section{Conclusions}

This study demonstrates the development and enhancement of logistic-regression-based rain-triggered lahar probability estimation models for real-time lahar forecasting using the lahar occurrence and rainfall record of the Belham valley, Montserrat, between April 2010 and April 2012. The incorporation of both antecedent rainfall and considerations for temporal catchment development into such models alongside the first-order lahar forecasting parameter of peak rainfall intensity is shown to improve lahar forecasting performance. Rainfall seasonality and catchment recovery are identified as important factors in the severity of the rain-triggered lahar hazard at the Soufrière Hills volcano, Montserrat, and by extension at similar volcanoes worldwide. Seasonal influences increase both the absolute number of lahars and the probability of lahar occurrence under predefined rainfall conditions during the wet season due to antecedent effects. Lahar probability is also shown to decline with time under given antecedent and peak rainfall intensity conditions as a product of catchment evolution. Our results demonstrate the potential for successful real-time prediction of secondary lahars using readily available input data, even in areas featuring strongly seasonal climates and periods of eruptive quiescence.

Data availability. The data underlying the research have been deposited and made available in the Research Data Leeds Repository (https://doi.org/10.5518/297; Jones et al., 2017). 


\section{Appendix A}

Receiver operating characteristic analysis is a statistical technique that is used to illustrate the diagnostic ability of a binary classifier system (i.e. a system that subdivides the elements of a given dataset into two groups, for example the presence or absence of a disease, a pass or a fail in a test). The method was first developed by electrical and radar engineers during World War II and has since been used in psychology, medicine, meteorology and the forecasting of natural hazards.

A graphical plot, or receiver operating characteristics curve, is often used to illustrate the effect of varying the value of the classifying parameter (for example the number of cancer cells per microlitre of blood or the pass mark in the previous example). The ROC curve is generated by plotting the true-positive rate against the false-positive rate as the value of the classifying or threshold parameter is changed. There are four possible outcomes from a binary classifier (Table A1): (i) correct prediction of an event that really did occur is a true positive, (ii) incorrect prediction of an event that did not occur is a false positive, (iii) predicting no event when an event does happen is a false negative, and (iv) correct prediction that no event occurs and no event really does occur is a true negative.

Imagine a situation where there are 200 patients undergoing a medical test, where alpha is some diagnostic threshold for having a medical condition. At a given value of alpha, the contingency table could resemble Table A2.

Here, the TPR is the number of true positives divided by the total number of predicted positives (both true and false), or $70 /(70+30)=0.70$.

The FPR is the number of false positives divided by the total number of predicted negatives (both true and false), or $28 /(28+72)=0.28$.

Thus, for this value of alpha, the corresponding point would plot at $(0.63,0.28)$ on Fig. A1 (the white square). By systematically varying the value of the threshold parameter alpha, a whole series of $2 \times 2$ contingency tables would be generated, producing an array of points in ROC space and hence a curve (the dashed line).

A $100 \%$ rate of prediction (all true positives) would plot at $(0,1)$ on Fig. A1 (the grey circle), whereas a $50 \%$ accurate rate of prediction (i.e. guessing the outcome of a coin toss) would plot at $(0.5,0.5)$. Random guesses thus plot along a diagonal line: points above the line represent predictions better than random guesses, points below the line predictions worse than random guesses.
Table A1. A $2 \times 2$ contingency table showing the possible outcomes of a binary classifier system.

\begin{tabular}{lll}
\hline Total population & Event happens & Event does not happen \\
\hline Predict it happens & True positive & False positive \\
\hline Predict it does not happen & False negative & True negative \\
\hline
\end{tabular}

Table A2. A $2 \times 2$ contingency table for 200 patients undergoing a medical test for the presence or absence of a condition.

\begin{tabular}{lrr}
\hline & $\begin{array}{r}\text { Has } \\
\text { condition }\end{array}$ & $\begin{array}{r}\text { Has no } \\
\text { condition }\end{array}$ \\
\hline Predict patient has condition & 70 & 30 \\
Predict patient has no condition & 28 & 72 \\
\hline
\end{tabular}

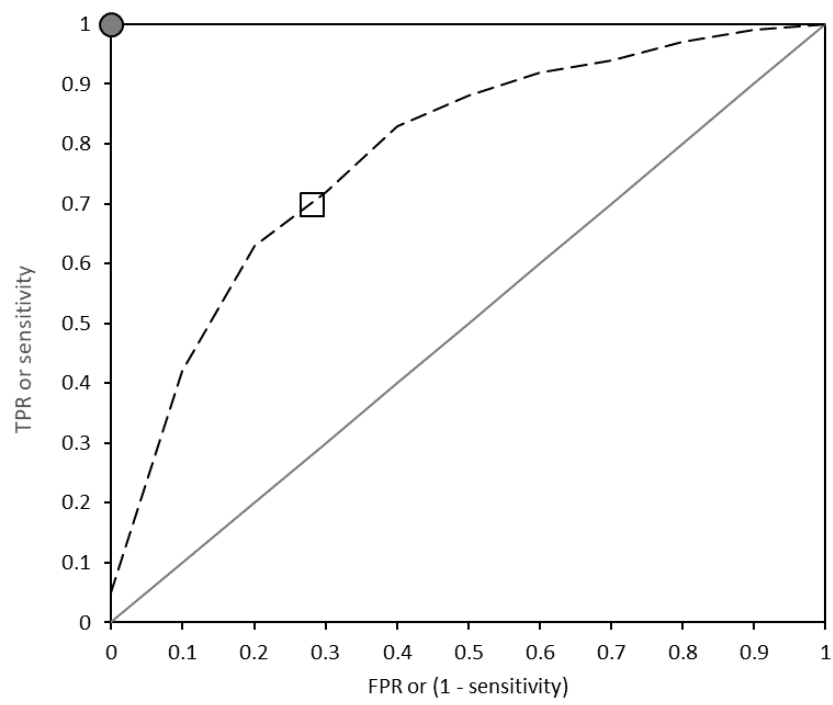

Figure A1. ROC space and plots of the prediction examples discussed in the text. 
Competing interests. The authors declare that they have no conflict of interest.

Acknowledgements. This research was supported by STREVA (NERC-ESRC consortium NE/J02483X/1), and we are thankful to the Montserrat Volcano Observatory for permission to use the lahar database and rain gauge dataset. We thank Thomas Pierson and Lucia Capra for their constructive reviews which helped improve the paper, and we thank editor Thomas Glade.

Edited by: Thomas Glade

Reviewed by: Lucia Capra and Thomas Pierson

\section{References}

Alexander, J., Barclay, J., Susnik, J., Loughlin, S. C., Herd, R. A., Darnell, A., and Crosweller, S.: Sediment-charged flash floods on Montserrat: the influence of synchronous tephra fall and varying extent of vegetation damage, J. Volcanol. Geoth. Res., 194, 127 138, https://doi.org/10.1016/j.jvolgeores.2010.05.002, 2010.

Arguden, A. and Rodolfo, K.: Sedimentologic and dynamic differences between hot and cold laharic debris flows of Mayon Volcano, Philippines, Geol. Soc. Am. Bull., 102, 865-876, https://doi.org/10.1130/00167606(1990)102<0865:saddbh>2.3.co;2, 1990.

Auker, M. R., Sparks, R. S. J., Siebert, L., Crosweller, H. S., and Ewert, J.: A statistical analysis of the global historical volcanic fatalities record, J. Appl. Volcanol., 2, 2, https://doi.org/10.1186/2191-5040-2-2, 2013.

Barclay, J., Johnstone, J. E., and Matthews, A. J.: Meteorological monitoring of an active volcano: implications for eruption prediction, J. Volcanol. Geoth. Res., 150, 339-358, https://doi.org/10.1016/j.jvolgeores.2005.07.020, 2006.

Barclay, J., Alexander, J., and Susnik, J.: Rainfall-induced lahars in the Belham Valley, Montserrat, West Indies, J. Geol. Soc. London, 164, 815-827, https://doi.org/10.1144/0016-76492006-078, 2007.

Bonadonna, C., Mayberry, G. C., Calder, E. S., Sparks, R. S. J., Choux, C., Jackson, P., Lejeune, A. M., Loughlin, S. C., Norton, G. E., Rose, W. I., Ryan, G., and Young, S. R.: Tephra fallout in the eruption of Soufriere Hills Volcano, Montserrat, Geo. Soc. Mem., 21, 483-516, https://doi.org/10.1144/gsl.mem.2002.021.01.22, 2002.

Capra, L., Borselli, L., Varley, N., Gavilanes-Ruiz, J. C., Norini, G., Sarocchi, D., Caballero, L., and Cortes, A.: Rainfall-triggered lahars at Volcán de Colima, Mexico: surface hydro-repellency as initiation process, J. Volcanol. Geoth. Res., 189, 105-117, https://doi.org/10.1016/j.jvolgeores.2009.10.014, 2010.

Cole, P. D., Calder, E. S., Sparks, R. S. J., Clarke, A. B., Druitt, T. H., Young, S. R., Herd, R. A., Harford, C. L., and Norton, G. E.: Deposits from dome-collapse and fountain-collapse pyroclastic flows at Soufriere Hills Volcano, Montserrat, Geo. Soc. Mem., 21, 231-262, https://doi.org/10.1144/gsl.mem.2002.021.01.11, 2002.

Collins, B. D. and Dunne, T.: Erosion of tephra from the 1980 eruption of Mount St Helens, Geol. Soc.
Am. Bull., 97, 896-905, https://doi.org/10.1130/00167606(1986)97<896:eotfte>2.0.co;2, 1986.

Doyle, E. E., Cronin, S. J., and Thouret, J. C.: Defining conditions for bulking and debulking in lahars, Geol. Soc. Am. Bull., 123, 1234-1246, https://doi.org/10.1130/B30227.1, 2011.

Fagents, S. A. and Baloga, S. M.: Toward a model for the bulking and debulking of lahars, J. Geophys. Res., 111, B10201, https://doi.org/10.1029/2005jb003986, 2006.

Fawcett, T.: An introduction to ROC analysis, Pattern Recogn. Lett., 27, 861-874, https://doi.org/10.1016/j.patrec.2005.10.010, 2006.

Fohrer, N., Berkenhagen, J., Hecker, J. M., and Rudolph, A.: Changing soil and surface conditions during rainfall - single rainstorm/subsequent rainstorms, CATENA, 37, 355-375, https://doi.org/10.1016/S0341-8162(99)00026-0, 1999.

Froude, M. J.: Lahar dynamics in the Belham River Valley, Montserrat: application of remote camera-based monitoring for improved sedimentological interpretation of post-event deposits, $\mathrm{PhD}$ Thesis, School of Environmental Science, University of East Anglia, Norwich, UK, 2015.

Froude, M. J., Alexander, J., Barclay, J., and Cole, P.: Interpreting flash flood palaeoflow parameters from antidunes and gravel lenses: An example from Montserrat, West Indies, Sedimentology, 64, 1817-1845, https://doi.org/10.1111/sed.12375, 2017.

Graf, W. L.: The rate law in fluvial geomorphology, Am. J. Sci., 277, 178-191, 1977.

Hosmer Jr., D. W., Lemeshow, S., and Sturdivant, R. X.: Applied Logistic Regression, John Wiley \& Sons, New York, USA, 2013.

Iverson, R. M.: Landslide triggering by rain infiltration, Water Resour. Res., 36, 1897-1910, https://doi.org/10.1029/2000wr900090, 2000.

Iverson, R. M., Reid, M. R., Logan, M., LaHusen, R. G., Godt, J. W., and Griswold, J. P.: Positive feedback and momentum growth during debris-flow entrainment of wet bed sediment, Nat. Geosci., 4, 116-121, https://doi.org/10.1038/NGEO1040, 2011.

Jones, R., Manville, V., and Andrade, D.: Probabilistic analysis of rain-triggered lahar initiation at Tungurahua volcano, B. Volcanol., 77, 68, https://doi.org/10.1007/s00445-015-0946-7, 2015.

Jones, R., Odbert, H. M., and Montserrat Volcano Observatory: Data associated with Real-time prediction of raintriggered lahars: incorporating seasonality and catchment recovery, https://doi.org/10.5518/297, 2017.

Komorowski, J. C., Legendre, Y., Christopher, T., Bernstein, M., Stewart, R., Joseph, E., Fournier, N., Chardot, L., Finizola, A., Wadge, G., Syers, R., Williams, C., and Bass, V.: Insights into processes and deposits of hazardous vulcanian explosions at Soufrière Hills Volcano during 2008 and 2009 (Montserrat, West Indies), Geophys. Res. Lett., 37, L00E19, https://doi.org/10.1029/2010gl042558, 2010.

Lavigne, F. and Suwa, H.: Contrasts between debris flows, hyperconcentrated flows and stream flows at a channel of Mount Semeru, East Java, Indonesia, Geomorphology, 61, 41-58, 2004.

Lavigne, F., Thouret, J. C., Voight, B., Young, K., LaHusen, R., Marso, J., Suwa, H., Sumaryono, A., Sayudi, D. S., and Dejean, M.: Instrumental lahar monitoring at Merapi Volcano, Central Java, Indonesia, J. Volcanol. Geoth. Res., 100, 457-478, https://doi.org/10.1016/S0377-0273(00)00151-7, 2000.

Leavesley, G., Lusby, G., and Lichty, R.: Infiltration and erosion characteristics of selected tephra deposits from the 1980 eruption 
of Mt. St. Helens, Washington, USA, Hydrol. Sci., 34, 339-353, 1989.

Major, J. J. and Yamakoshi, T.: Decadal-scale change of infiltration characteristics of a tephra-mantled hillslope at Mount St Helens, Washington, Hydrol. Process., 19, 3621-3630, https://doi.org/10.1002/Hyp.5863, 2005.

Major, J. J., Pierson, T. C., Dinehart, R. L., and Costa, J. E.: Sediment yield following severe volcanic disturbance a two-decade perspective from Mount St. Helens, Geology, 28, 819-822, https://doi.org/10.1130/00917613(2000)28<819:Syfsvd>2.0.Co;2, 2000.

Manville, V., Hodgson, K. A., Houghton, B. F., Keys, J. R. H., and White, J. D. L.: Tephra, snow and water: complex sedimentary responses at an active, snow-capped stratovolcano, Ruapehu, New Zealand, B. Volcanol., 62, 278-293, 2000.

Marcial, S., Melosantos, A., Hadley, K., LaHusen, R., and Marso, J.: Instrumental lahar monitoring at Mount Pinatubo, in: Fire and Mud, Eruptions and Lahars of Mt Pinatubo, Philippines, edited by: Newhall, C. and Punongbayan, R., PHIVOLCS/University of Washington Press, Quezon City/Seattle, USA, 1015-1023, 1996.

Mead, S., Magill, C., and Hilton, J.: Rain-triggered lahar susceptibility using a shallow landslide and surface erosion model, Geomorphology, 273, 168-177, https://doi.org/10.1016/j.geomorph.2016.08.022, 2016.

Ogawa, Y., Daimaru, H., and Shimizu, A.: Experimental study of post-eruption overland flow and sediment load from slopes overlain by pyroclastic-flow deposits, Unzen volcano, Japan, Geomorphologie, 13, 237-246, https://doi.org/10.4000/geomorphologie.3962, 2007.

Okano, K., Suwa, H., and Kanno, T.: Characterization of debris flows by rainstorm condition at a torrent on the Mount Yakedake volcano, Japan, Geomorphology, 136, 88-94, 2012.

Pierson, T. C. and Major, J. J.: Hydrogeomorphic effects of explosive volcanic eruptions on drainage basins, Annu. Rev. Earth Pl. Sc., 42, 469-507, https://doi.org/10.1146/annurev-earth-060313$054913,2014$.

Pierson, T. C., Janda, R. J., Umbal, J. V., and Daag, A. S.: Immediate and long-term hazards from lahars and excess sedimentation in rivers draining Mt. Pinatubo, Philippines, U.S. Geological Survey Water-Resources Investigations Report, 92-4039, 183-203, available at: https://pubs.er.usgs.gov/publication/wri924039 (last access: 5 December 2017), 1992.

Rodolfo, K. and Arguden, A.: Rain-lahar generation and sediment-delivery systems at Mayon Volcano, Philippines, in: Sedimentation in Volcanic Settings, edited by: Fisher, R. and Smith, G., SEPM, Special Publication 45, 71-87, https://doi.org/10.2110/pec.91.45.0071, 1991.
Schumm, S. A. and Rea, D. K.: Sediment yield from disturbed earth systems, Geology, 23, 391-394, https://doi.org/10.1130/00917613(1995)023<0391:Syfdes>2.3.Co;2, 1995.

Segerstrom, K.: Erosion studies at Paricutin, State of Michoacan, Mexico, USGS Bulletin, 965-A, 164 pp., available at: https: //pubs.er.usgs.gov/publication/b965A (last access: 5 December 2017), 1950.

Smith, G. A. and Fritz, W. J.: Volcanic influences on terrestrial sedimentation, Geology, 17, 375-376, 1989.

Stinton, A. J., Cole, P. D., Stewart, R. C., Odbert, H. M., and Smith, P.: The 11 February 2010 partial dome collapse at Soufriere Hills Volcano, Montserrat, Geo. Soc. Mem., 39, 133152, https://doi.org/10.1144/m39.7, 2014.

Thouret, J. C., Oehler, J. F., Gupta, A., Solikhin, A., and Procter, J. N.: Erosion and aggradation on persistently active volcanoes-a case study from Semeru Volcano, Indonesia, B. Volcanol., 76, 857, https://doi.org/10.1007/S00445-014-0857Z, 2014.

Todisco, F.: The internal structure of erosive and nonerosive storm events for interpretation of erosive processes and rainfall simulation, J. Hydrol., 519, 3651-3663, https://doi.org/10.1016/j.jhydrol.2014.11.002, 2014.

Tungol, N. and Regalado, T.: Rainfall, acoustic flow monitor records, and observed lahars of the Sacobia River in 1992, in: Fire and Mud, Eruptions and Lahars of Mt Pinatubo, Philippines, edited by: Newhall, C. and Punongbayan, R., PHIVOLCS/University of Washington Press, Quezon City/Seattle, USA, 1023-1033, 1996.

Van Westen, C. and Daag, A.: Analysing the relation between rainfall characteristics and lahar activity at Mt Pinatubo, Philippines, Earth Surf. Proc. Land., 30, 1663-1674, 2005.

Waldron, H. H.: Debris flow and erosion control problems caused by the ash eruptions of Irazu Volcano, Costa Rica, United States Geological Survey, Bulletin 1241-I, 37 p., available at: https: //pubs.er.usgs.gov/publication/b1241I (last access: 5 December 2017), 1967.

Wang, B., Kim, H.-J., Kikuchi, K., and Kitoh, A.: Diagnostic metrics for evaluation of annual and diurnal cycles, Clim. Dynam., 37, 941-955, https://doi.org/10.1007/s00382-010-0877-0, 2010.

Wischmeier, W. and Smith, D.: Predicting rainfall erosion losses a guide to conservation planning, Agricultural Handbooks (USA) No. 537, US Department of Agriculture, Washington, D.C., USA, 1978.

Yamakoshi, T. and Suwa, H.: Post-eruption characteristics of surface runoff and sediment discharge on the slopes of pyroclasticflow deposits, Mt Unzen, Japan, Transactions, Japanese Geomorphological Union, 21, 469-497, 2000. 